\title{
GÜNCEL SANATI (KAVRAMSAL) ANLAMAYA ÇALIŞMAK
}

\author{
Öğr. Gör. Dr. Şükran Bulut*1 \\ ${ }^{*}$ Cumhuriyet Üniversitesi Güzel Sanatlar Eğitimi Bölümü Resim-İş Öğretmenliği A.B.D. Sivas
}

\begin{abstract}
Özet
Bu çalışmada, sanat eserinin görünmeyen yönlerinin, düşünsel boyut (kavramsal sanat) bağlamında günümüz sanat anlayışına göre ortaya çıkarılması ve yorumlanması amaçlanmıştır. Araştırmanın problem durumunu, günümüz (kavramsal) sanat anlayışının düşünsel yapısını, anlamaya ve anlatmaya çalışmaktır. Araştırmanın metodolojisi kurgulanırken öncelikle kavramsal sanat ile ilgili bilgiler, yorumlar ve değerlendirmeler ele alınmıştır. Kavramsal sanatın ne olduğu ve kavramsal sanat anlayışının düşünsel boyutu yönünde kapsamlı bir literatür taraması yapılmışıı. Araştırma betimsel bir araştırmadır. Araştırma, kaynak tarama yöntemi ve betimsel yöntem kullanılarak yürütülmüştür.
\end{abstract}

Anahtar Kelimeler: Kavram, düşünsel boyut, kavramsal sanat

\section{TRYING TO UNDERSTAND CONTEMPORARY ART (CONCEPTUAL)}

\begin{abstract}
This project focuses on unfolding and interpreting the invisible dimensions of art through a conceptual analysis of the theme of crew in contemporary art works. Putting the theme of crew to the center, the project aims at extricating the cognitive essence of the contemporary conceptual art. Drawing from a large multinational literature and several branches of art, this dissertation gathers together mythology, literature, visual arts, and personal narratives around the selected theme in order to propose a cognitive and conceptual interpretation of the crew within the context of contemporary conceptual art. An extended literature review on philosophical and cognitive development of conceptual art is also included.
\end{abstract}

Key words: conceptual, invisible dimensions, conceptual art

\section{Giriş}

Güncel sanat anlayışı çok yönlü çalışmaya elverişlidir. Güncel sanat aslında eskimeyen bir kavramdır. lç̧inde bulunduğu zamanın günceli olarak geçmişte, o günü yaşayan sanatçılar için de geçerli olan bir kavramdır. Globalleşmeye bağlı olarak sanatçının içinde bulunduğu zamana, yere, yaşadıklarına, göre evrilerek kendi tarzına ulaşması ve düşünsel olanı ifade etme biçimini seçmesidir. "Türkiye'de ağırlıklı olarak 1990'larda yavaş yavaş sanat piyasasında yerini almaya başlayan güncel sanatın ele alınması gereken bir takım sosyokültürel değişimlerin sonucu olduğu yadsınamaz bir olgudur"(Ersen,2010:48).

Malzemenin belki de en önemsiz olduğu dönemin içinde yaşayan sanatçı, daha rahat üretebilmektedir. Düşüncenin önemini bilen sanatçı sadece sanatsal üretimle yetinmemekte aynı zamanda yaptıklarını yazarak, yaşayarak, kendi bedenini kullanarak, araziyi, sokak duvarlarını, bulduğu ready- made (hazır yapım) ürünlerinin üzerine bir şeyler yaparak güncel sanatı / kavramsal sanatı gerçekleştirmektedir. Güncel sanat asında yeni bir şeyler üretmenin hazzından çok, neler yapabilirim?'in sınırlarını zorlamak isteyen farklı insanların ortak buluşma noktasıdır. Seçilen yollar farklıık gösterse bile çıkış noktaları benzerdir. Duchamp'ın "Pisuar'ı", Kosuth'un "Üç Sandalye'si", Sol Le witt'in söylemleri, Andy Warhol'un serigraf baskıyla çoğaltıımış “Ünlülerin portreleri” veya "Brillo Kutuları" gibi

Kavramsal sanat dediğimizde aklımıza gelen ilk şey sanatın estetik beğeniye hitap etme kaygısından uzak, düşünsel yanıyla, işin felsefi yönüyle, ready- made (hazır yapım) olarak her tür malzemenin kullanıldığı çalışmalar gelmektedir. Kosuth'a göre sanat, önce düşüncesinde, zihninde oluşmaktadır. Düşündüğü,

\footnotetext{
${ }^{1}$ Yazar mail adresi: sukranblt@gmail.com
} 
zihninde oluşturduğu ve sonuçlandırdığı şey zaten onun anlayışına göre sanattır. Sonrasında ise fikrinin görüntüye dönüşmesi safhasında ne tür ifade aracı kullanıldığının pek bir önemi yoktur. Bu; yazılarla fikirlerin ifadesi olabilir, video olabilir, hazır yapım bir ürün üzerine bir imza, yazı, boya, harita, vs. ile de olabilir. Bu görüşe göre sanatçı yaptığına "sanat,, diyorsa o sanattır. Kavramsal sanat sergi alanlarını da reddeder. Galeri ve müzelere bağı olmak zorunda değildir. Her an, her yerde, yapılan işler sergilenebilir.

Danto'ya göre; "Andy Warhol bize sanatın ne olduğunu söylememiş olabilir, ama sanatla felsefi bağlamda ilgilenenlere önemli ölçüde malzeme sağlamış, yeni düşünce yolları açmıştır. Sözcüklerle değil ama paylaştığımız dünyayı sanata çevirerek ve dolayısıyla sanatın ne olduğunu sordurarak yapmıştır felsefesini,, (Danto, 1999:83'dan aktaran, Yılmaz, 2013:261). Geçmişten günümüze sanatın pek çok tanımı yapıımıştır ve yapılacaktır. Estetik beğeniden yola çıkarak yapılan tanımların pek çoğu güncel sanat tanımını karşılamamktadır. Daha çok kavramlar üzerinden ortaya çıkan ve bir felsefesi olan güncel sanat kendi tanımını düşünsellik yoluyla ifade etmek, üzerinden zaten yapmaktadır. Bu anlamda tanımlar ile kısıtlanamaz olduğunu da göstermektedir.

Günümüz sanatı Akay'a göre 21. Yüzyılda daha çok deneyseldir. Bunun yanı sıra güncel sanat 'malzemelerle yapılan bir refleksiyon'dur' ve sanatçı artık kavramlarla değil malzemelerle düşünmektedir. Bundan dolayı güncel sanat içinde boya ve desenin yanı sıra fotoğraf, dijital çalışmalar, videolar, da yer almaktadır (Akay, 2005:116-117'den aktaran, Evren, 2008:4).20. yy.da güncel sanat, sanatın bir sermaye olarak görülmesine karşı çıkan anlayışla ortaya konulmuştur. Sanatın sadece sanat galerilerinde ve müzelerde olması yerine her an her yerde yapılabilirliği ve daha geniş izleyici kitlesine ulaşabilmeyi hedeflemiştir.

21. yy.da güncel sanat yaparken çok farklı malzemelerin kullanılması, izleyenler üzerinde şaşırtıcı etki yaratırken aynı türden malzemelerin geçmişte sanat için düşünülmesi bile imkânsızdı. "Kavramsal sanat pratikleri olarak anılan (land art, performans sanatı, fakir sanat, video sanatı vb.) etkinlikler, genellikle düşünceyi sanat eserinin önüne koyan, doğa ve farklı malzemelerle etkileşimli, anlığı yakalayan bir sürece dikkat çekerler,,(Alp, 2013:.52).

Sırp sanatçı Marina Abromovic zihinsel ve bedensel sanatın sınırlarını zorlayarak saatlerce bir sandalye de hareketsiz oturarak ve sadece karşısındakinin gözlerinin içine bakarak acı çekmenin görüntüsünü vermektedir. Canlı performanslarını genelde bir müzenin girişinde ya da içerisinde bir masa ve iki başında duran sandalye ile gerçekleştirmiştir. Birine kendisi diğerine sevgilisi Ulay oturmuş birbirlerinin gözlerinin içine bakmışlardır. İleyicilerde kısa süreli sanatçının karşısındaki sandalyeye oturup gözlerine bakmışlardır.Abromovic 1960'larda ortaya çıkan Body Art'ın önemli temsilcilerindendir. Bedenin, kendisinin malzeme olarak kullanılması başı başına şaşırtıcıdır. Yapılanların anlaşılabilmesi ise uzun bir süre almıştır.

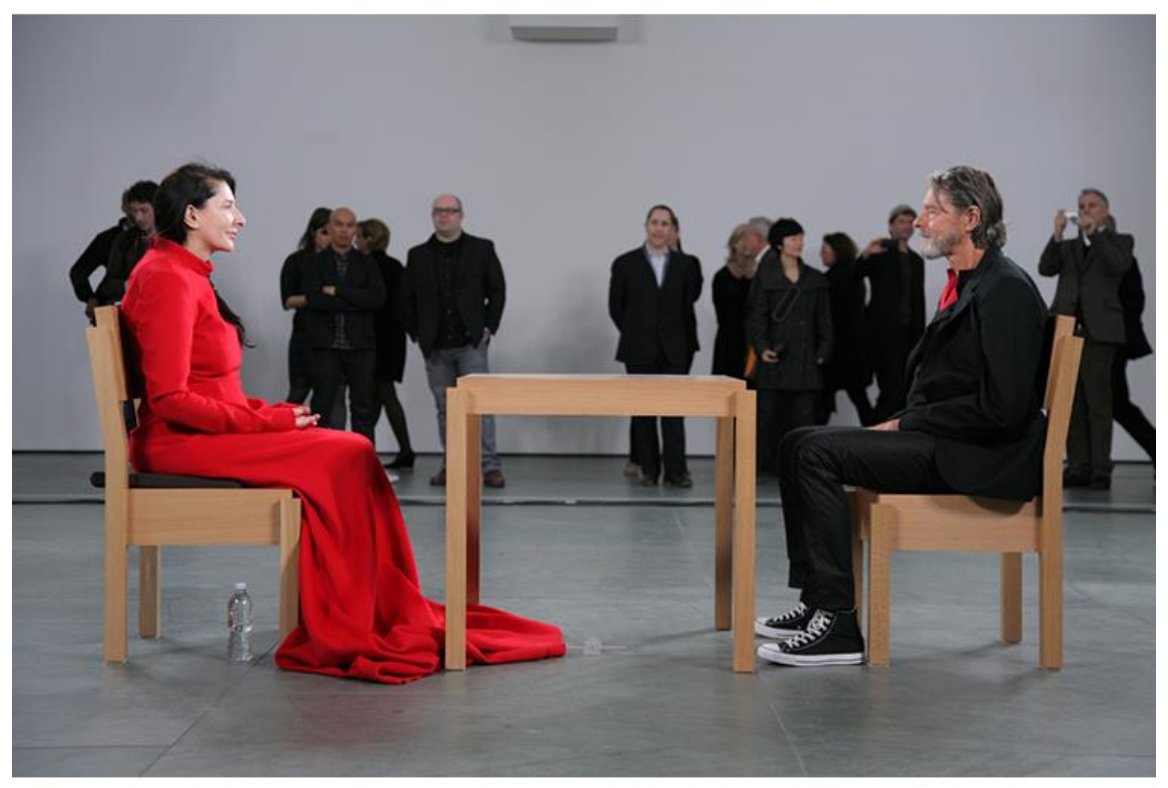

Resim.1.1 Marina Abromovic ve Sevgilisi Ulay (Karşııklı Oturma Performansında) MOMA 2010 / New York. 
Land Art arazide yapılan çalışmalardan meydana gelmektedir. İlk akla gelen isim ise Robert Smithson ve yaptığı işi "Spiral Jetty" dir. Madenler, çöller, kayalıklar, donmuş nehirler, üzerinde, kısacası doğada meydana gelen ve getirilen görüntülerden ibarettir. Doğada bir iz bırakmak ve yok olan doğaya dikkat çekmek için yapılan tüm çalışmalar için bazen işçi çalıştııılması, vinçlerden yardım alınması, büyük bütçeler ayrıması, hatta sponsor bulunması gerekir. Tüm yapılanlar ise kalıcı değildir. Bu nedenle de genellikle sanatçı araziye elinde belgeler, çalışma notları, haritalar ile açıklayıcı günlüklerini götürür. Kendisi ya da profesyonel bir fotoğrafçı ile çalışarak oradaki görüntüleri çeker, kaydeder, videoya alır. Sonra bu çalışmaları sergileyerek, satarak paraya dönüştürebilir. Arazide yapılan çalışmayı satması bir galeride sergilemesi mümükün değildir.

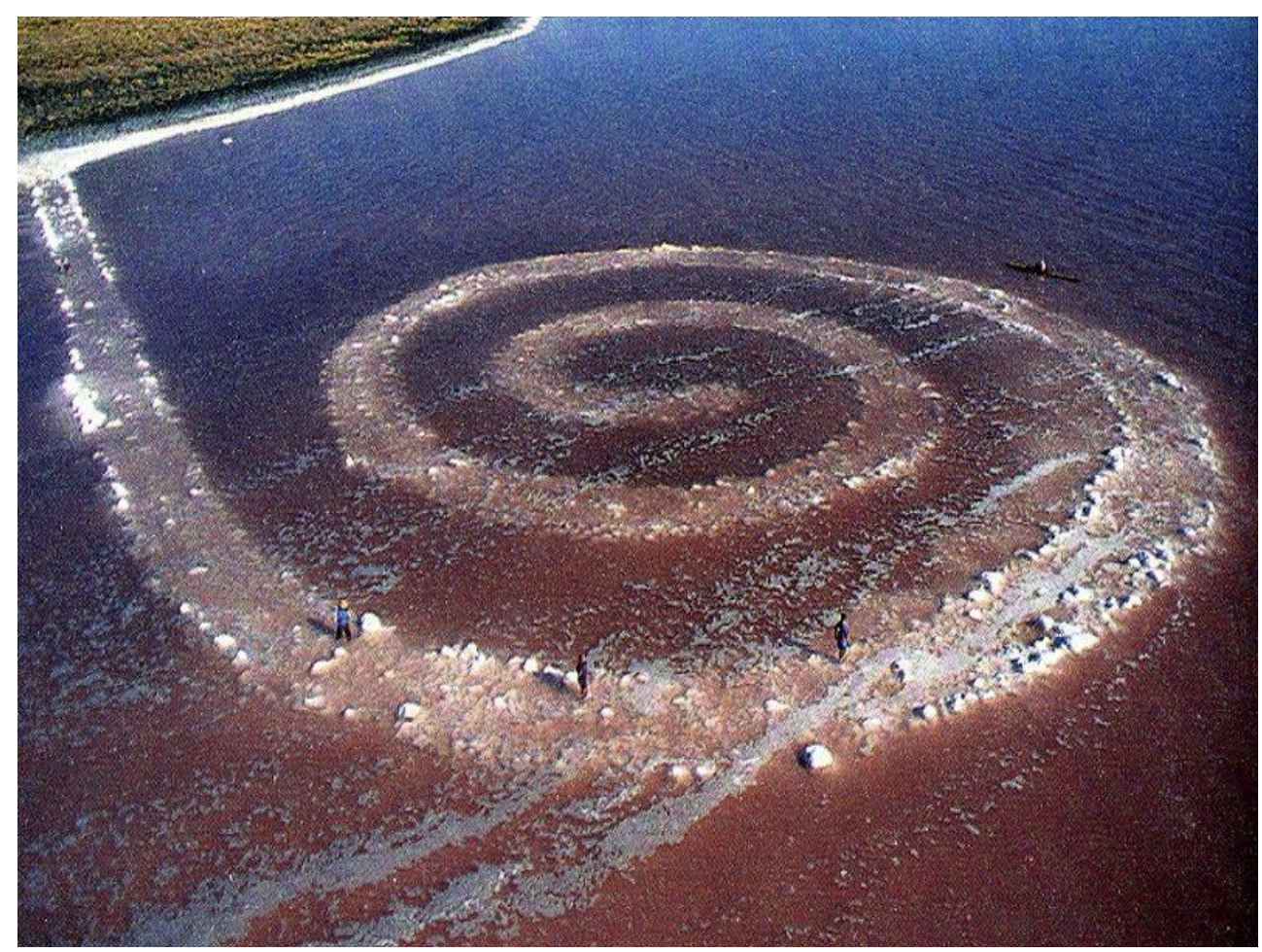

Resim.1.2. Robert Smithson “Spiral Art” Büyük TuzGöl'ü /Utah /1970/ABD.

Madra; “(...) kavramsal sanatı savunması gereken ilk kişinin ben olmadığını belirtmeliyim, çünkü başlangıçta kavramsal sanatın arkasındaki felsefeye derinlemesine saldırdım. Bu felsefeye göre bir şeyi düşünmek, o şeyin var sayıımasına yetiyor, ya da sanatçının yazdığı bir metnin okunması, yapıtın varlığının düşlenmesine yetiyor. Bu temel noktalarda kavramsal sanata karşıyım. Biz görsel sanatlar alanında çalışıyoruz, eğer görünmeyen şeylerle uğraşırsak büyük bir çelişkiye düşmüş oluruz" (Madra,1989:4).

Madra, görsel alanda çalışan birinin görünmeyen işlerle uğraşmasının tezatlığına vurgu yaparken haklı olabilir çünkü estetik beğeniye ve retinal görüntüye yönelik çalışmalarda bu doğrudur. Kavramsal sanatın iddia ettiği daha doğrusu savunduğu ise çalışmaların felsefi anlamda, düşünce boyutunda yeterli olduğudur. Görüntüye ihtiyacının olmadığını, nesnesiz sanatın özgürleştirdiğini, düşüncelerini görsel olarak gerçekleştirme zorunluluğunun olmadığını savunur. İlle de görsel boyuta taşınacaksa da bunun bir tekniğe bağlı kalmadan herhangi bir yolla ifade edilebileceğini, dilsel ve yazınsal olarak yapılabileceğini, ready-made ürünler üzerinden nesnesiz biçimde kavramsal sanatın gerçekleşebileceğini savunur.

Giderer, "Resmin Sonu" isimli kitabında "Kavramsal Sanat, sanat nesnesine karşı olmasıyla bilinmektedir. Modernizm açısından bir son noktadır, resmi, heykeli, hatta üç boyutlu minimal yapıları reddetmiştir. O da Greenberg'e karşı 1960'ların ortasında doğan bir tepkidir. Dolayısıyla Kavramsal sanatın retinal resme bir tepki olduğu söylenebilir" demektedir (Giderer, 2003:150). 
Geçmişten günümüze sürekli olarak sanatçının kendinden öncekileri sorguladığı ve eleştirel bakışla yaklaştığı, sürekli yenilik arayışıyla hareket ettiği bilinmektedir. Bu hareketin temelinde ki karşı çıkışlar, kendini daha iyi ifade edebilmek, geçmişten aldıklarını geleceğe aktarabilmek, kendi içselliğini, sanata bakışını kendince yorumlayarak ve geçmişin etkisinde kalmayarak, hatta geçmişten sıyrılarak ve tüm engelleri kaldırarak (özellikle malzeme, yer, mekân, gibi) sorunlardan kurtulmaktır.

Kandinsky'ye göre de "her sanat eseri zamanının çocuğu, çoğu zaman da duygularımızın anasıdır. Böylece her kültür dönemi kendine özgü ve artık tekrarlanmaz bir sanat yaratır” (Kandinsky, 2009:).

Güncel sanat yapanlar, yaptıklarını bu gün için kurgular iken zamanın ötesine taşımak, taşıyabilmek gibi bir derdi yoktur. Günümüz sanatının ve sanatçısının çıkış noktası düşünceyi esas olarak almasıdır. Sürekli problem çözme halinde olan sanatçı yapacağı işler için uzun zaman düşünmektedir. Güncel sanatın arka plânında bir kurgu vardır. İşte bu nedenle kavramsal sanat çalışan sanatçıların amacı estetik beğeniden uzakta sadece düşündürmeye yöneliktir.

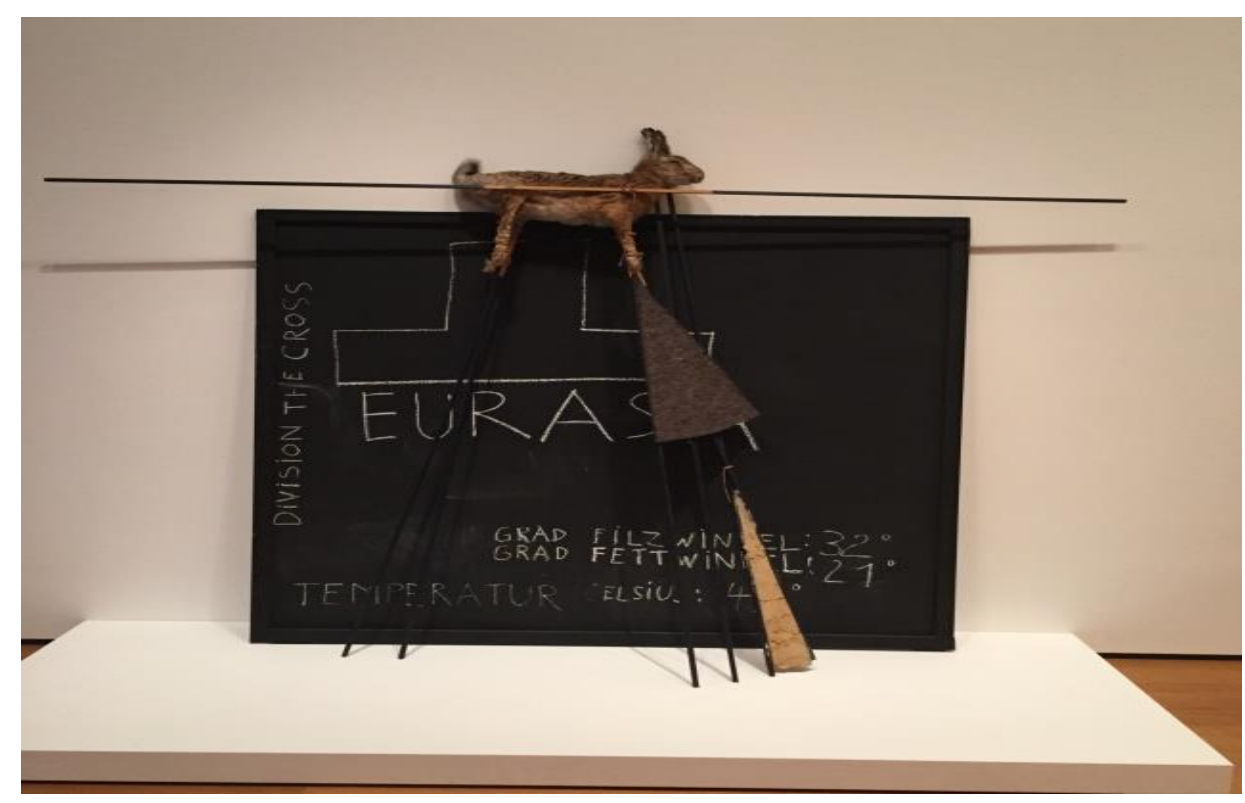

Resim.1.3. "Eurasia Siberian Symphony,„Joseph Beuys,1963, MOMA Museum, New York (Fotoğraf: Şükran Bulut,2016).

Joseph Beuys'un üzerinde hala tebeşirle yazılmış ders notlarının durduğu öğrencilerine ders anlattığı kara tahtanın üstüne iç organları boşaltııı, içi doldurulmuş "ölü tavşanı" da yerleştirerek izleyenler üzerinde aynı şoku yaratır. İzleyiciye "bu da nedir?" Dedirten çalışması ile Beuys ölü bir tavşana ders anlatmanın imkânsızlığını göstererek, insanlarla ilişki kurmanın ve onlara ders anlatmanın güçlüğüne vurgu yapmak istemiştir. 
INÖNÜ ÜNIVERSITESI KÜLTÜR VE SANAT DERGISi

İnönü University Journal of Culture and Art

Cilt/Vol. 4 Sayı/No. 1 (2018): 69-76

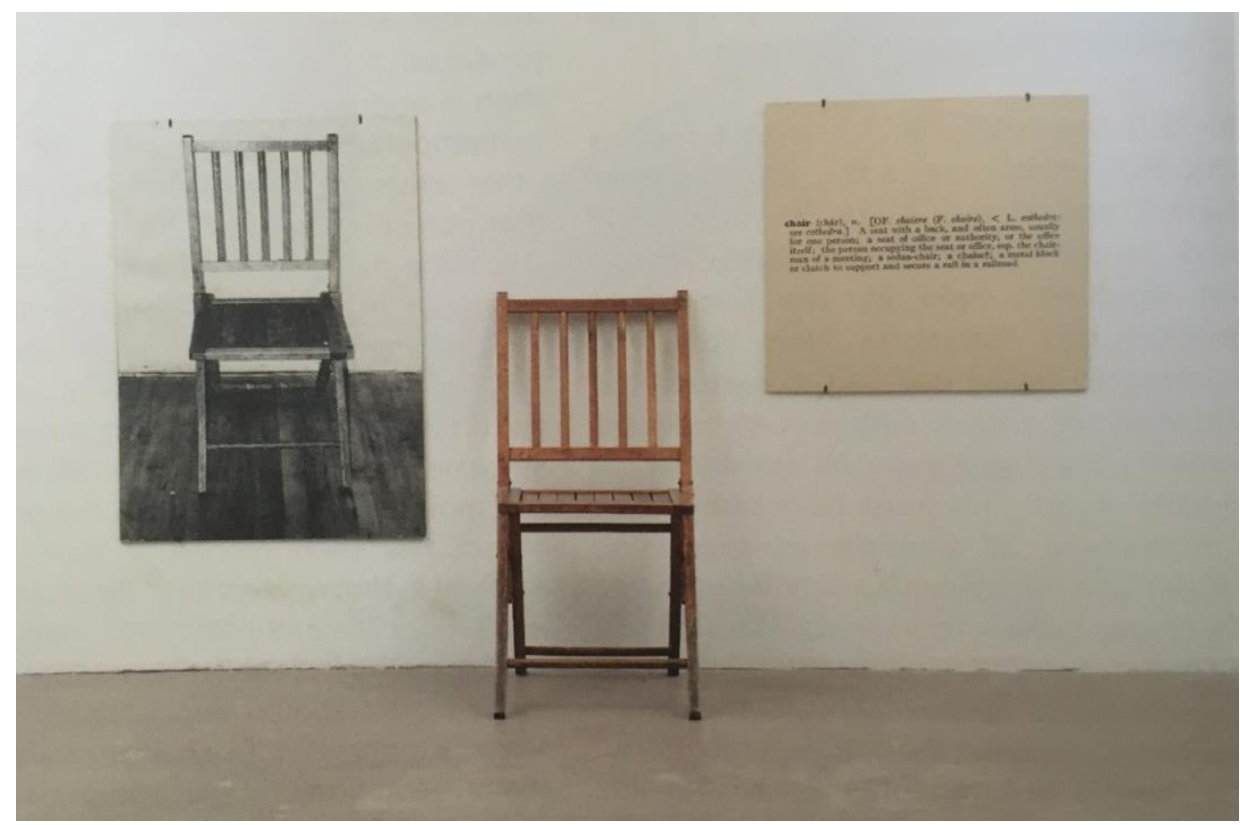

Resim.1.4. Joseph Kosuth, "One and Three Chairs", 1966, Boyutları:Sandalye'nin Fotoğrafı 91,5x61,1cm., Yazılı metin panosu $61 \times 61.3 \mathrm{~cm}$., Sandalye $82 \times 37,8 \times 53 \mathrm{~cm}$.

Kosuth ise "Üç Sandalye" adlı çalışmasıyla izleyeni şaşırtır. Sandalye'nin kendisi, sandalyenin fotoğrafı ve sandalyenin tanımının yapıldığı yazınının yan yana konulmasıyla üçlemeyi sağlamıştır. Burada izleyeni düşündürmek amaçtır. Sanatın arka plânında yatan felsefeye odaklanmanız istenir. Gördüğünüz ve gördüğünüzü sandığınız şey ile onun tanımı önünüze konulmuştur.

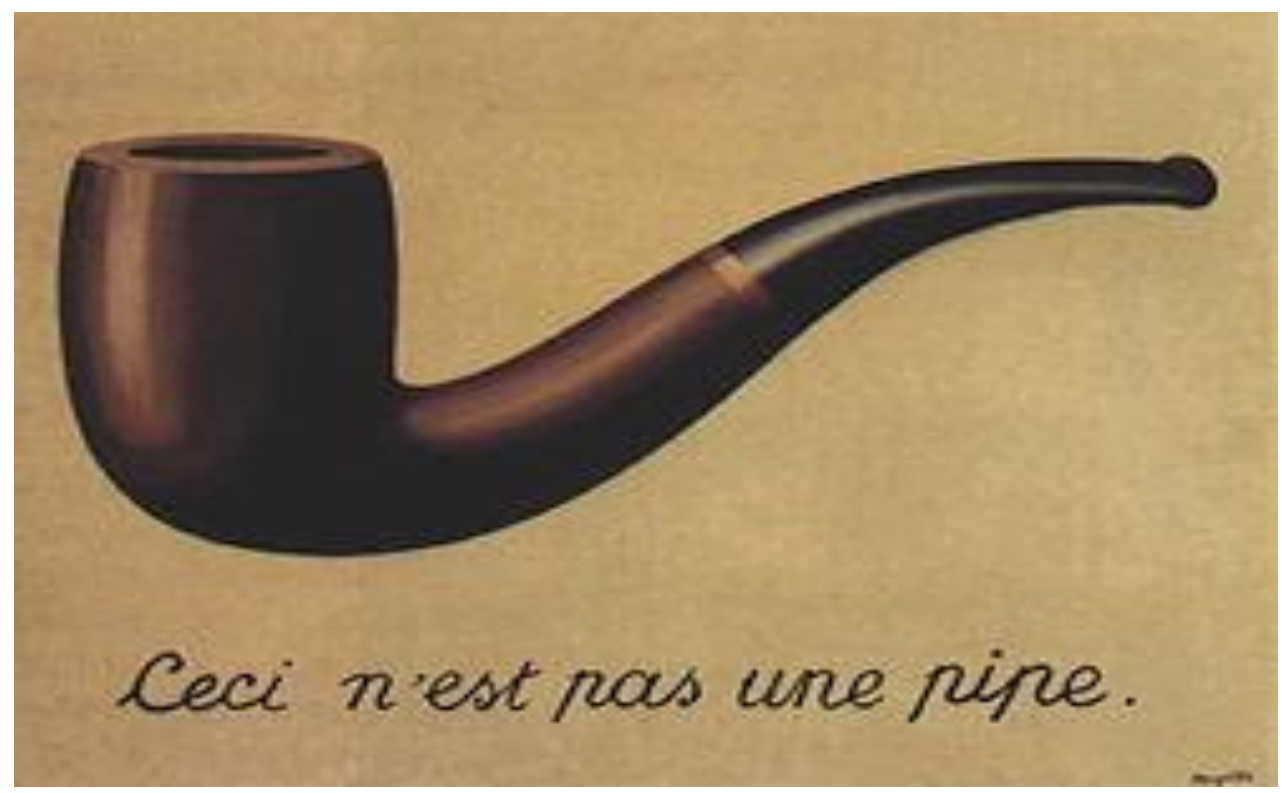

Resim.1.5. Rene Magritte, Oil on Canvas, 1928-1929, 63,5 cm × 93,98 cm (250 in × 3,700 in), Los Angeles, California.

Rene Magritte'in "Bu bir pipo değildir!” adlı çalışmasında Rene Magritte “yanılsama ve gerçeklik kavramlarının görsel sanatlarda ki yapıtlar üzerinden sorgulamasını sıklıkla yapmıştır. "Ceci n'est pas une pipe" (Bu bir pipo değildir) isimli tablosunda resmin gerçekte dümdüz bir yüzey olduğunu ve gerçekliğin bir 
nesne olmadığını" (Dikmen, 2015:295) net olarak vurgulamıştır. Tabii ki bu resim kendi döneminin güncel sanatının üzerinden düşünceyi sorgulayan, kafa karışıklığı yaratan bir çalışmadır. Sanatçı ne demek istemiştir? Neden o yazıyı yazmıştır. Gördüğümüz bir pipo'mudur değil midir? Görülen bir pipodur ama olmadığı iddia edilmektedir. Söylenilmek istenen piponun resmi olduğudur ama kendisi değildir. Kavram olarak o bir pipo olabilir ve onun görüntüsü olabilir ama kendisi olamaz. Güncel sanat pek çok kavram üzerinden sorgulatarak, düşündürerek izleyene anlatmak istediğini de yaşatmaktadır. Bu nedenle belki de güncel sanatın anlaşılması kendi dönemi içerisinde zaman alacaktır.

Atakan, "Kosuth için önemli olan, sanatın işlevi ve bu işlevi neden gördüğüdür" ve "Kosuth için sanatçı olmak, sanatın doğasını sürekli olarak sorgulamak demektir" (Atakan,1997;51-59).

Sorgulamak güncel sanatın pratiğidir. Yorumlanmazsa ve düşünceler dilsel olarak yazılıp, üzerinde tartışıımazsa, kısacası izleyici de merak uyandıramazsa, yapılan çalışmalar hedefine ulaşmakta başarısızlığa uğrayabilir.

Sol LeWitt (1969) "Kavramsal Sanat izleyicinin gözü veya duyumlarından çok zihnini uyarmak için yapılır" (Sol Le Witt'den 1969'dan akt. Bağatır, 2011:26). İzleyicinin zihnini uyarmak, gözüne ve duyularına hitap etmekten çok önemlidir. Kosuth, Beuys, Warhol, Rene Magritte, yaptıkları çalışmalarıyla izleyenlerini şaşırtarak, düşündürmüşlerdir. Picasso ve Dali ise dönemlerinin güncel sanatını yaparak, farklı çalışmalarıyla düşündürten sanatçılardandır.

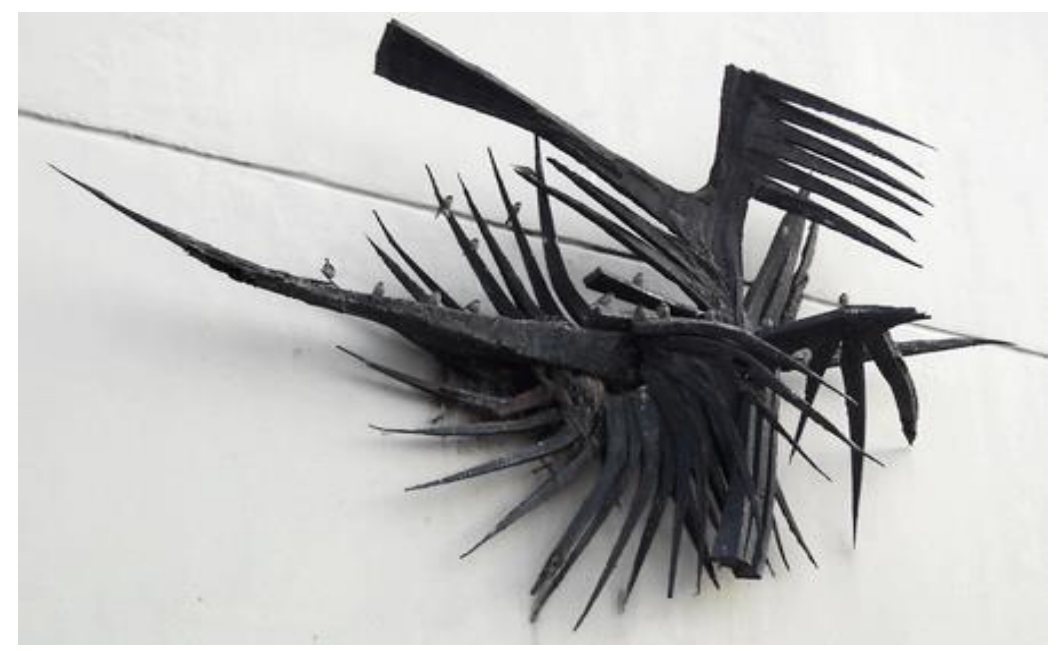

Resim.1.6. Kuzgun Acar, "Soyut Kuşlar,, Heykeli 1966

Türkiye'de güncel sanat çalışan isimlerin en başında ise 1960'lardan itibaren heykel sanatçıları Füsun Onur, Kuzgun Acar, resim sanatçıları Altan Gürman, Bedri Baykam, Sarkis gibi isimler gelmektedir.

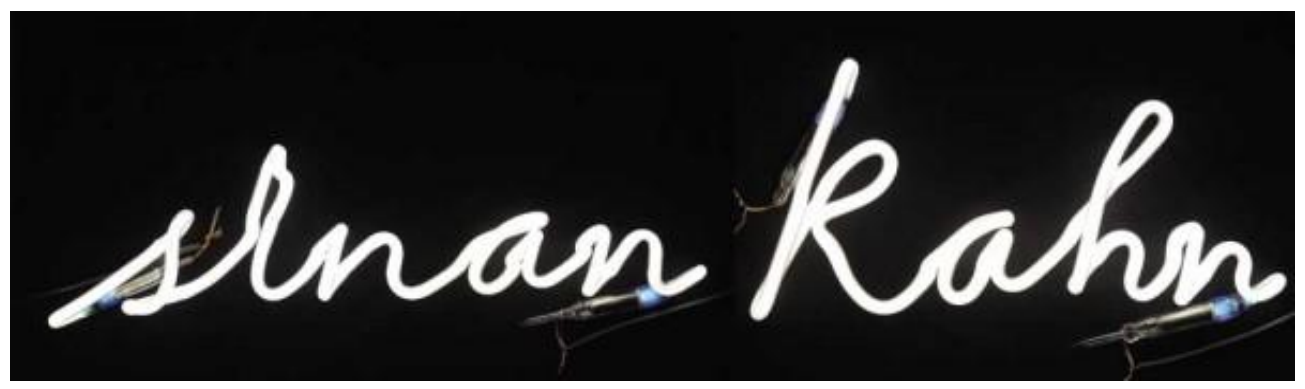

Resim.1.7. Sarkis "Sinan Kahn" White Neon Ligthing, 2010,Edition of 5

Kavramsal sanat çalışan sanatçıların çalışmaları izleyenler için farklı bir pencereden bakmayı sağlayarak, merak etmelerine ve düşünmelerine vesile olmuştur. Resimlerin üzerinde yer alan yazılar, boş bir çerçeve, 
atık malzemeler ile yapılan heykeller, dönemin politik, siyasi yönetim biçimini anlatan hazır- nesne üzerine çalışmalar da o dönemin sansasyonel kavramsal çalışmaları olmuştur.

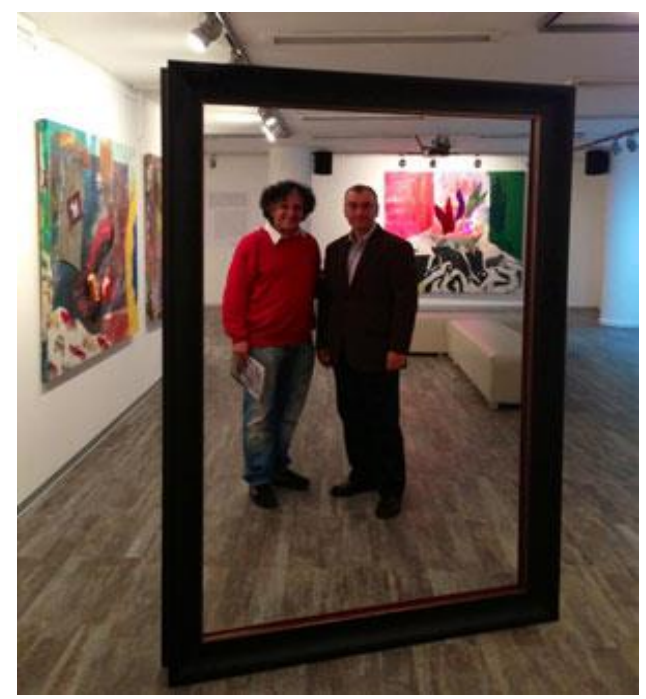

Resim.1.8. It has been done before, Bedri Baykam-2013

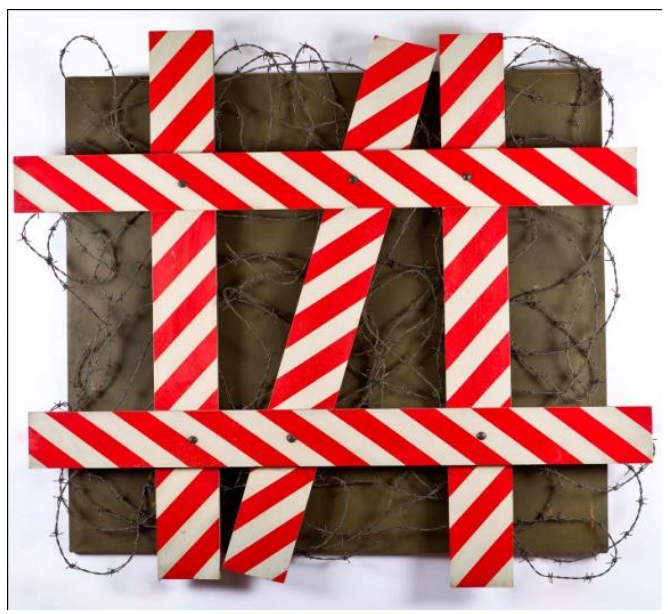

Resim.1.9. Altan Gürman, "Montaj 5", Tahta üz. Selülozik Boya ve Dikenli Tel, 140x140x9 cm. 1967-İstanbul

Lotringer'e göre; "Sanat bugün hiç olmadığı kadar başarıııır. Ama hala sanat mıdır? Sanat, maddi mallar gibi piyasa taleplerini karşılamak için durmadan çalışırken, statüsünü sorgulamak yerine, öne çıkmanın tadına varmaktadır. Günümüzde sanatın yegâne varlık nedeni: Kendi kendini sanat olarak yeniden icat etmektir"(Lotringer, 2010).

Günümüzde sanat, çok kolları olan bir ahtapot gibi her yerde, her an, üretilip, tüketilen verimli, özgür sınırlanamaz haldedir. Tony Godfrey, kavramsal sanatın gelişimini anlatırken, "temsil edilenlerin (dünyadaki şeyler, illüzyon, derinlik, doku, hatta belki duygular) ve ortaya konanların (dokunmuş kumaş üzerindeki pigmentler) ne olduğunu, çözümlemeye yönelik girişiminden dolayı Kübizm'i resimdeki dönüm noktası, olarak değerlendirir (Godfrey'den aktaran Erenus, 1998).

Kübizim Picasso ile ilk varlığını kanıtladığında anlaşılması ve çözülmesi beklenen problem gibiydi. Bu nedenle insanlar biraz mesafeli ve tepkiliydiler. Havada uçuşan bir sürü soru işaretleri vardı. Neden? Niçin? Nasıl? Niye? Zaman içinde tüm soruların cevapları onu izleyenler ve eleştirenler tarafından kendiliğinden verilecekti. Tabii ki üzerinde epeyce düşündükten ve anlamaya çalıştıktan sonra mümkün olacaktı. 
Tapies'e göre "Bir devrin belli bir uslûba yönelik beğenisi bir kez doyuma ulaştı mı, bir bakıma heyecanlandırma mekanizmaları bir kez yıpranıp sanatçının (numarası) açığa çıktı mı, sanatçı eserinin etkili olması için başka biçimler bulmak zorundadır" (Tapies, 1971).

Güncel sanat, kıtalar arası etkileşime açık, video, internet ağı, ses kaydı, görseller üzerinden anında ulaşılarak tartışmaları yapılabilen haldedir. İnternet üzerinden, grup ve kişisel olarak açılan sergiler önce yadırgansa da sonraları çok pratik gelmeye başlamıştır.Günümüzde sergilemek istediğiniz çalışmalarınızı kendi hesabınız üzerinden uluslararası anlamda galeri ve aracıları ortadan kaldırarak anında hiç bir masraf ve zahmete girmeden sunabilirsiniz

Yılmaz'a göre; “ Bir sanatçının, sanatın kavramsal bir biçimini kullanması demek, bütün plân ve kararların daha ilk baştan yapılması ve uygulamanın ise sadece bir ayrıntı olması demektir"(Yılmaz, 2001).

\section{SONUÇ}

Burada vurgulanan her dönemin kendi içinde güncel sanatını yaptığı ve yaşadığıdır. Güncel sanat o dönemin sosyolojik yapısına göre de şekillenecektir. İlgi, intiyaçlar kullanılıp tüketildikçe yenileriyle yer değiştirecektir. Merak duygusu ile düşündürmeye yönelik olarak sanatın arka plânında ki felsefe ve kurgu sanatçının en sancılı ve deneysel yönüdür. Güncel sanat düşünen, üreten, araştıran, sanatçının ortaya koyduklarından ibaret değildir. Asıl önemlisi sanatçının beyninde oluşan düşünceleridir.Malzemenin çok da önemi yoktur. Yapılan çalışmalar için tutulan defterler, çizim yapılan kağıtlar, notlar, haritalar, gazeteler, yemek yenilen kağıt tabaklar, kendiliğinden zaten malzemedir. Sanatçı da, yaptığı işin felsefesini, dilselliğe, yazınsalığa tartışmalara taşıyandır.Hayata ayak uydurmaktan çok sorgulayan, eleştiren her yerde malzemesiz, nesnesiz ve hazır ürünler ile çalışabilenlerdir. Sergileme mekanlarına intiyacı yoktur çünkü her yerde çalışmalarını isterse gösterebilir. Yazılarını her şeyin üzerine yazabilir, basabilir, çoğaltabilir. Tartışabilir, anlatabilir. Genellikle güncel sanata ait bu tür çalışmalar ona uygun yerde oluşturulur, belgelenir, sonra video, fotoğraf vd. şeklinde kayıt altına alınarak saklanır. Bu nedenle galeri, müze vb. yerlerde saklanma güçlüğü nedeniyle çok talep görmezler. Yeni yeni sanat galerileri ve müzeler bu tür çalışmaları ya da görsellerini(CD, fotoğraf, video, vd.) koleksiyonlarına almak için çaba göstermektedirler.

\section{KAYNAKLAR}

1. Alp, K.Ö. (2013).“Sanatın Temsili ve Postmodern Sanatta Temsil,, Süleyman Demirel Üniversitesi Güzel Sanatlar Fakültesi Hakemli Dergisi, 13(12), s.52-53.Isparta.

2. Atakan, N.(1997). "Arayışlar" Çev.Zeynep Rona, s.51-59,YKY,İstanbul (Mimar Sinan Üniversitesinde yapılmış Doktora Tezinden alıntıdır).

3. Baykam, B. (1993). Post-Duchamp Krizi. Bilgi Olarak Sanat Olgu Olarak Sanatçı Yeni Ontoloji.s.78, İstanbul:Plastik Sanatlar Derneği Yayınları.

4. Bağatır, R.D.(2011). "Nesnenin Ötesi: Kavramsal Sanatın Dayanak Noktaları" Adnan Menderes Üniversitesi Güzel Sanatlar Eğitimi Bölümü, Aydın.

5. Dikmen, B. (2015). Görsel Sanatlar Bağlamında Gerçeklik ve Yanılsama. s.295, Uluslararası Sanat Sempozyumu, Bodrum Güzel Sanatlar Fakültesi. Muğla: Muğla Sıtkı Koçman Üniversitesi Matbaası.

6. Giderer, H.E.(2003). "Resmin Sonu" s.150, Ütopya Yayınevi, Ankara

7. Godfrey, T. (1998). Conceptual Art. Akt: Erenus, 1998, Phaidon Press Inc- New York.

8. Kandinsky, V. (2009). Sanatta Zihinsellik Üstüne. Çev:Tevfik Turan, Hayalbaz Kitap Sanat Kuramları, İstanbul.

9. Ersen,L. (2010).Türkiye'de 1990 Sonrası Güncel Sanat ve Kültürel Kimlik Kavramı, L Ersen - Sanat ve Tasarım Dergisi, 2010 - dergipark.ulakbim.gov.tr, Adnan Menderes Üniversitesi, Aydın.

10. Evren, (2008) Akay, 2005:116-117'den aktaran,:4)

11. Lotringer, S.(2010). Sanat Korsanlığı. Jean Baudrillard, Sanat Komplosu, İstanbul: Yeni Sanat Düzeni ve Çağdaş Estetik.

12. Madra, B. (1989). Istanbul'u Mesken Tuttu. Cumhuriyet Gazetesi, 16 Ocak 1989, İstanbul.

13. Tapies, A. (2014). Sanat Pratiği. Çev:İsmet Birkan. Ankara: Dost Kitabevi Yayınları.

14. Yılmaz, M. (2001). "Sanatçıları Okumak ya da Hayali Söyleşiler"s. 175, Ütopya Yayınevi,

15. Ankara.

16. Yılmaz, M. (2013). "Modernden Postmoderne Sanat"s.261 Ütopya Yayınevi, Ankara.

17. http://erayem.blogspot.com.tr/2010/09/land-art.html Saat:12.10 Tarih: 13/10/2017

18. https://www.google.com.tr/search?q=marina+abramovic+ve+ulay\&tbm= Saat/15.29/ Tarih:13/10/2017 